Jahangirnagar University J. Biol. Sci. 5(2): 41-50, 2016 (December)

\title{
Phytoconstituents, bioactivity and antioxidant potential of some commercial brinjal (Solanum melongena L.) cultivars of Bangladesh
}

\author{
Fakhruddin Ali Ahmed", Sanzida Mubassara and Tania Sultana \\ Department of Botany, Jahangirnagar University, Savar, Dhaka-1342, Bangladesh
}

\begin{abstract}
Comparative phytochemical composition, antibacterial activity, cytotoxicity and antioxidant potentiality of seven brinjal cultivars Solanum melongena L. were determined. Strong presence of carbohydrates, phenolic glycosides and weak presence of alkaloids, falvonoids, tannins, terpenoids, steroids and saponins were recorded in all the brinjal varieties. Antibacterial assay of brinjal extracts showed varying degree of sensitivity against both gram-positive and gramnegative bacteria. In cytotoxicity assay, the $\mathrm{LC}_{50}$ values ranged between 59.91 to $216.45 \mathrm{mg} / \mathrm{ml}$ after 6 hours was an indication of poor cytotoxic potential of brinjal cultivars. The DPPH free radical scavenging activity ranged between $80.79 \%$ to 87.64 although the phenolic content was found between 6.082 to $9.292 \mathrm{mg} \mathrm{GAE} / \mathrm{g}$ among the brinjal cultivars.
\end{abstract}

Key words: Antioxidants, Phytoconstituents, Solanum melongena.

\section{INTRODUCTION}

Brinjal (Solanum melongena L.) is an important solaneceous crop of tropics and subtropics. Brinjal fruit (unripe) is primarily consumed as cooked vegetable. In addition, it has some medicinal uses like antihaemorrhoidal and hypotensive effect and used as an antidote to poisonous mushrooms (Sudheesh et al., 1999). It is a good source of minerals and vitamins and is rich in total water soluble sugars, free reducing sugars, and proteins (Noda et al., 1998). Some phytochemicals of vegetables are strong antioxidants and are thought to reduce the risk of chronic disease by protecting against free-radical damage, by modifying metabolic activation and detoxification of carcinogens, or even influencing processes that alter the course of tumor cells (Herrera et al., 2009). Steroidal glycoalkaloids found in potatoes, tomatoes, and brinjals may lower blood cholesterol and offer protection against infection by Salmonella tvphimurium (Friedman et al., 2000 and Gubarev et al., 1998). Mahmood et al. (2012) determined the cytotoxic effect of methanolic extract of Datura innoxia and Solanum surrattense on brine shrimps. But still there is no record on assessing cytotoxicity of brinjal cultivars on brine shrimps. Furthermore, in recent years, much emphasis has been placed on antioxidant properties of plant parts. Anthocyanins, an important group of naturally occurring phenolic compounds found in brinjal peel (Mazza et al., 2004).

Brinjal fruit with different size, shape and color can be seen in vegetable-markets in all over Bangladesh. Diversity in fruit morphology of brinjal gives rises to the question whether they contain similar type of phytochemicals or have identical bioactivity. From these point of view the present investigation was carried out to make a comparative

\footnotetext{
* Corresponding author. E-mail: < faahmed_ju@yahoo.com>
} 
profile on phytoconstituents, antibacterial activity, cytotoxicity and antioxidant potential of seven brinjal cultivars collected from vegetable markets Dhaka, Mymensingh and Jessore districts of Bangladesh.

\section{MATERIALS AND METHODS}

Seven commercial brinjal cultivars were collected from different vegetable markets of Dhaka, Mymensingh and Jessore and named as collection no. JUBS1 to JUBS7 (Plate 1). Here, JUBS1 and JUBS7 were local cultivars known as 'Kanta begun' and 'Kamranga begun' collected from Jessore and Mymensingh districts respectively. Rests of the five cultivars were known as 'hybrid begun' were collected from different vegetables markets of Dhaka and Savar.

The collected fruit samples were chopped into pieces and sun-dried separately under open sunlight followed by drying in a hot air oven (Gallenkamp) at reduced temperature (not more than $50^{\circ} \mathrm{C}$ ) for 48 hours to make suitable for grinding. After that fruits chips were ground into coarse powders using high capacity grinding mill and were stored in air-tight container with necessary markings for identification and kept in cool, dark and dry place for the investigation. About $500 \mathrm{~g}$ powder was digested with $1500 \mathrm{ml}$ of $100 \%$ of methanol for three days accompanying with occasional shaking and stirring. The whole mixtures then underwent a coarse filtration by a piece of clean, white cotton material followed by filtration using Whatman no.1 filter paper. This digestion procedure was repeated twice for each of the seven sample to obtain maximum amount of extract. The extract was concentrated at $45^{\circ} \mathrm{C}$ under reduced pressure using a rotary evaporator and resultant residue was stored under refrigerated conditions until further studies.

The crude extracts of fruits were subjected to different chemical tests to find out the qualitative presence of phytochemicals which were identified by characteristic color changes using standard procedure as described for alkaloids (Harborne, 1973), steroids (Trease \& Evans, 1989), phenolics and flavonoids (Awe \& Sodipo, 2001), saponins and cardiac glycosides (Sofowora, 1993), tannins (Odebiyi \& Sofowora, 1978) terpenoids and saponins (Obadoni \& Ochuko, 2001).

Antibacterial sensitivity test was estimated by the disc diffusion method following Bauer et al. (1966). The bacterial strains used for the experiment were collected as pure cultures from Microbiology laboratory, Department of Botany, Jahangirnagar University, Savar, Dhaka. Gram positive bacteria (Bacillus subtilis, B. cereus) and Gram-negative bacteria (Escherichia coli ATCC25922, Vibrio cholera, Pseudomonas sp., Salmonella typhi, Salmonella sp., Serratia sp., Erwinia sp., Proteus mirabilis, Shigella flexneri, Staphylococcus aureus ATCC25923) were considered for the test. $100 \mu \mathrm{l}$ of bacterial cell suspension was spread throughout the plates by spread plate method. The sample discs, the standard antibiotic disc and the control disc were placed gently on the previously marked zones in the nutrient agar plates. The plates were then inverted and kept in an incubator at $37^{\circ} \mathrm{C}$ for 24 hours. After incubation, the antimicrobial activities of the test 
materials were determined by measuring the diameter of the zones of inhibition in millimeter with a transparent scale.

The cytotoxicity assay was carried out following Brine shrimps (Artemia salina) lethality bioassay as described by Meyer et al., 1982. The antioxidant activities of the extracts were measured on the basis of the scavenging activity of the stable 1,1-diphenyl-2picrylhydrazyl (DPPH) free radical following the method described by Blois (1958) and Aoshima et al. (2004). The absorbance of each of the samples were taken at $517 \mathrm{~nm}$ after 30 min of incubation of DPPH solution and the samples.

The total concentration of phenolic compound (TPH) in methanol extracts were determined by Folin-Ciocalteu method (Vinson et al., 1995) using the Folin-Ciocalteu reagent (FCR) with Gallic acid (GA) as the standard and expressed as milligram (mg) Gallic acid equivalents $(\mathrm{GAE}) / \mathrm{g}$ of extract. Results are expressed as mean $\pm \mathrm{SE}$ for a given number of observations $(n=3)$. The level of significance was set at $p$ value of 0.05 .

\section{RESULTS AND DISCUSSION}

The qualitative chemical examination of crude methanolic $(\mathrm{MeOH})$ extract of different brinjal plant samples have been presented in Table 1. Phytochemical analysis of fruit extracts of the seven brinjal cultivars (sample no. JUBS1 to JUBS7) showed strong presence of carbohydrate and phenolic glycosides including cardiac and anthraquinone glycosides and weak presence of alkaloids, falvonoids, tannins, terpenoids, steroids and saponins.

According to Ghani (2003) the presence of phytochemicals may account for their various pharmacological activities. Chinedu et al. (2011) reported on the presence of phytosterols, saponins and vitamin $\mathrm{C}$, cardiac glycosides, steroids and tannins, and trace amount of terpenoids from S. aethiopicum. However, Nicoletti et al. (2008) mentioned that the Solanum sp. contains bioactive compounds like alkaloids, flavonoids, steroids and saponins. Agoreyo et al. (2012) showed that phytate, oxalate and tannin were higher in the round variety of $S$. melongena than that the oval variety. In contrast, the present findings indicated that amount of various phytochemicals did not alter with types of samples.

The antibacterial property of methanolic extracts of brinjal fruits have been tested against twelve bacterial strains to evaluate antimicrobial potential. The findings suggest that fruit extracts of brinjal cultivars were moderately active against the gram-positive and gramnegative bacteria. The antibacterial activity of JUBS2, JUBS3, JUBS4 and JUBS5 showed similar propensity of sensitivity against B. subtilis, B. cereus, E. coli ATCC25922 and Pseudomonas sp whereas JUBS1 and JUBS7 showed greater sensitivity against $S$. aureus ATCC25923 and V. cholerae along with B. subtilis, B. cereus, E. coli ATCC25922 and Pseudomonas sp. 


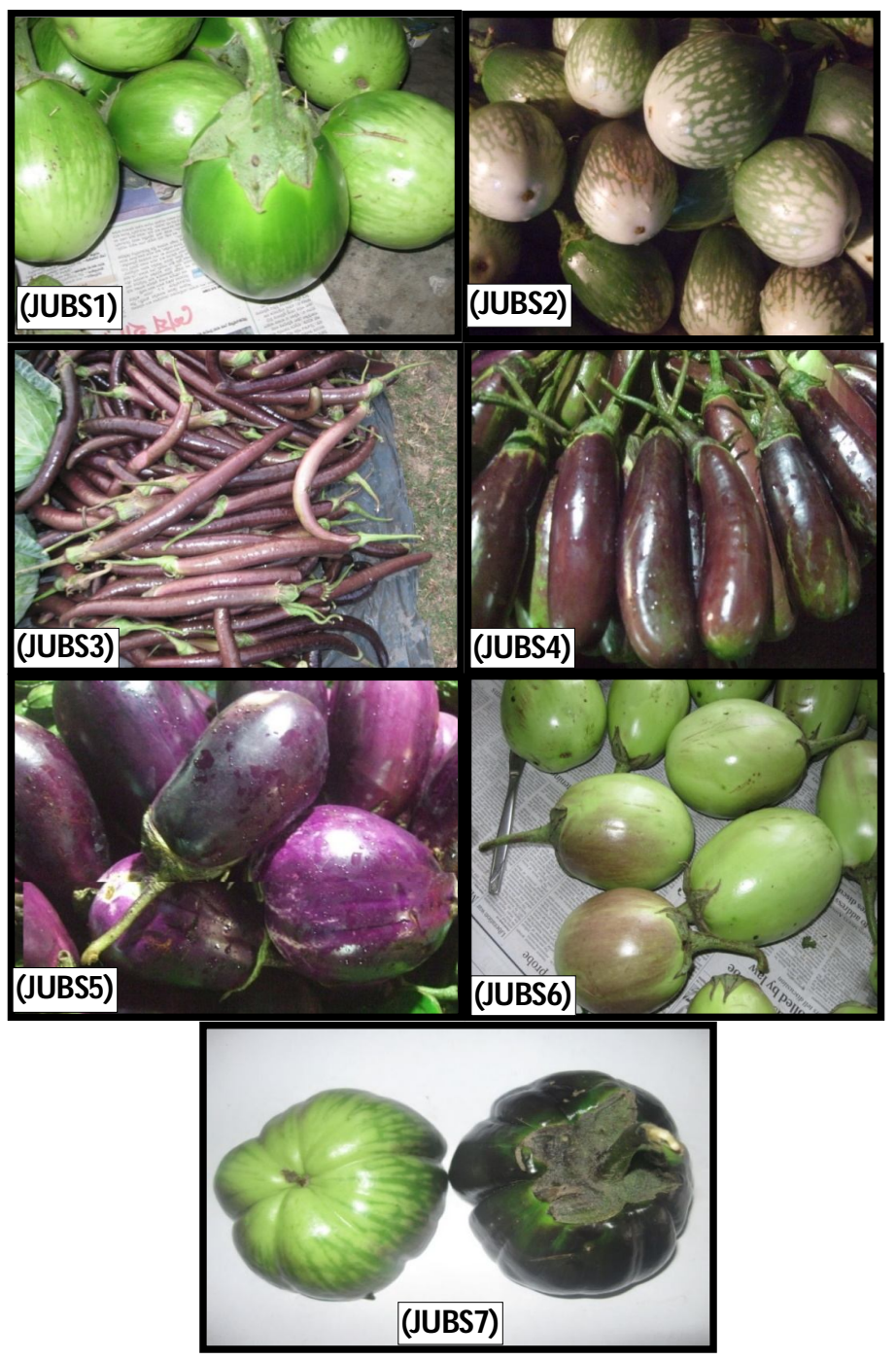

Plate 1. Commercial brinjal cultivars collected from different vegetable markets of Bangladesh

Largest inhibition zone $18.5 \mathrm{~mm}$ was observe $B$. cereus at $30 \mathrm{mg} /$ disc concentration by JUBS1 followed by $16.4 \mathrm{~mm}$ at $30 \mathrm{mg} /$ disc concentration by JUBS7 (Fig. 1). Cowan (1999) mentioned that plants which have been found in vitro to have antimicrobial property contains wide variety of secondary metabolites, such as tannins, terpinoids, alkaloids and flavonoids. Anushia et al. (2009) reported on the antibacterial activities of the $S$. melogena investigated against some common human pathogenic bacteria which was in favor of present findings. Sinden et al. (1986) reported that glycoalkaloides found in root of brinjal have antibacterial and diuretic properties. 
Table 1. Qualitative chemical examination of fruit extracts of different brinjal cultivars

\begin{tabular}{|c|c|c|c|c|c|c|c|c|c|}
\hline \multirow{2}{*}{$\begin{array}{l}\text { SI } \\
\text { no. }\end{array}$} & \multirow{2}{*}{$\begin{array}{c}\text { Name of the } \\
\text { phytochemicals }\end{array}$} & \multirow{2}{*}{$\begin{array}{l}\text { Name of the } \\
\text { reagents/test }\end{array}$} & \multicolumn{7}{|c|}{ Brinjal cultivars } \\
\hline & & & JUBS1 & \begin{tabular}{|l|} 
JUBS2 \\
\end{tabular} & JUBS3 & \begin{tabular}{|l|} 
JUBS4 \\
\end{tabular} & \begin{tabular}{|l|} 
JUBS5 \\
\end{tabular} & JUBS6 & JUBS7 \\
\hline \multirow[t]{2}{*}{01} & Carbohydrates & Molish's & $(++)$ & $(++)$ & $(++)$ & $(++)$ & $(++)$ & $(++)$ & $(++)$ \\
\hline & & Fehling & $(++)$ & $(++)$ & $(++)$ & $(+++)$ & $(+++)$ & $(++)$ & $(+++)$ \\
\hline \multirow[t]{5}{*}{02} & Alkaloids & Hagger's & $(+)$ & $(+)$ & $(+)$ & $(+)$ & $(+)$ & $(+)$ & $(+)$ \\
\hline & & Wagner's t & $(+)$ & $(+)$ & $(+)$ & $(+)$ & $(+)$ & $(+)$ & $(+)$ \\
\hline & & Mayer's & $(+)$ & $(+)$ & $(+)$ & $(+)$ & $(+)$ & $(+)$ & $(+)$ \\
\hline & & Draggendrof's & $(+)$ & $(+)$ & $(+)$ & $(+)$ & $(+)$ & $(+)$ & $(+)$ \\
\hline & & $\begin{array}{l}\text { Tannic acid } \\
\text { solution }(10 \%)\end{array}$ & $(+)$ & $(+)$ & $(+)$ & $(+)$ & $(+)$ & $(+)$ & $(+)$ \\
\hline \multirow[t]{3}{*}{03} & Glycosides & $\mathrm{FeCl}_{3}$ & $(+++)$ & $(++)$ & $(++)$ & $(++)$ & $(++)$ & $(++)$ & $(+++)$ \\
\hline & $\begin{array}{l}\text { a. Cardiac } \\
\text { glycosides }\end{array}$ & $\begin{array}{l}\text { Keller } \\
\text { Killiani's }\end{array}$ & $(+)$ & $(+)$ & $(+)$ & $(+)$ & $(+)$ & $(+)$ & $(+)$ \\
\hline & $\begin{array}{l}\text { b. } \\
\text { Anthraquinon } \\
\text { e glycosides }\end{array}$ & $\begin{array}{l}\text { Modified } \\
\text { Borntrager's }\end{array}$ & $(+)$ & $(+)$ & $(-)$ & $(+)$ & $(+)$ & $(+)$ & $(-)$ \\
\hline \multirow[t]{3}{*}{04} & Flavonoids & Lead acetate & $(+)$ & $(+)$ & $(+)$ & $(+)$ & $(+)$ & $(+)$ & $(-)$ \\
\hline & & Alkali & $(+)$ & $(+)$ & $(+)$ & $(+)$ & $(+)$ & $(+)$ & $(-)$ \\
\hline & & Conc. $\mathrm{H}_{2} \mathrm{SO}_{4}$ & $(-)$ & $(-)$ & $(-)$ & $(-)$ & $(-)$ & $(-)$ & $(-)$ \\
\hline \multirow[t]{2}{*}{05} & $\begin{array}{l}\text { Terpenoids } \\
\text { a. Terpene }\end{array}$ & $\begin{array}{l}\mathrm{CHCl}_{3}+\text { Conc. } \\
\mathrm{H}_{2} \mathrm{SO}_{4}\end{array}$ & $(++)$ & $(+)$ & $(+)$ & $(+)$ & $(+)$ & $(-)$ & $(++)$ \\
\hline & b. Triterpene & $\begin{array}{l}\mathrm{CHCl}_{3}+\text { Acetic } \\
\text { anhydride }\end{array}$ & $(+)$ & $(+)$ & $(+)$ & $(+)$ & $(+)$ & $(+)$ & $(+)$ \\
\hline 06 & Steroids & Salkowski & $(+)$ & $(+)$ & $(+)$ & $(+)$ & $(+)$ & $(+)$ & $(+)$ \\
\hline \multirow[t]{3}{*}{07} & Phenols & $\mathrm{FeCl}_{3}$ & $(+)$ & $(+)$ & $(+)$ & $(+)$ & $(+)$ & $(+)$ & $(-)$ \\
\hline & & Ammonia & $(-)$ & $(-)$ & $(-)$ & $(-)$ & $(-)$ & $(-)$ & $(-)$ \\
\hline & & Lead acetate & $(+)$ & $(+)$ & $(+)$ & $(+)$ & $(+)$ & $(+)$ & $(-)$ \\
\hline 08 & Saponins & Foam & $(+)$ & $(+)$ & $(+)$ & $(+)$ & $(+)$ & $(+)$ & $(+)$ \\
\hline
\end{tabular}

Our results indicated that the inhibition zone production by the extracts were proportional to the concentration of extracts and local cultivars (JUBS1 and JUBS2) showed rather greater antibacterial activity than of the rest. Al-Janabi \& Al-Rubeey (2010) given an acceptable explanation for the antimicrobial activities of $S$. melogena based on the presence of phenolic and alkaloid compounds, especially chlorogenic acid that considered the predominant phenolic compound found in all varieties of brinjals.

Brine Shrimp Cytoxicity Test (BSCT) is used as a useful tool to screen a wide range of chemical compounds for their cytotoxicities. It has been well utilized to screen out physiologically active compound as well. In cytotoxicity assay, the $\mathrm{LC}_{50}$ values that ranged between 59.91 to $216.45 \mathrm{mg} / \mathrm{ml}$ after 6 hours was an indication of poor cytotoxic potential 
46

Ahmed et al.

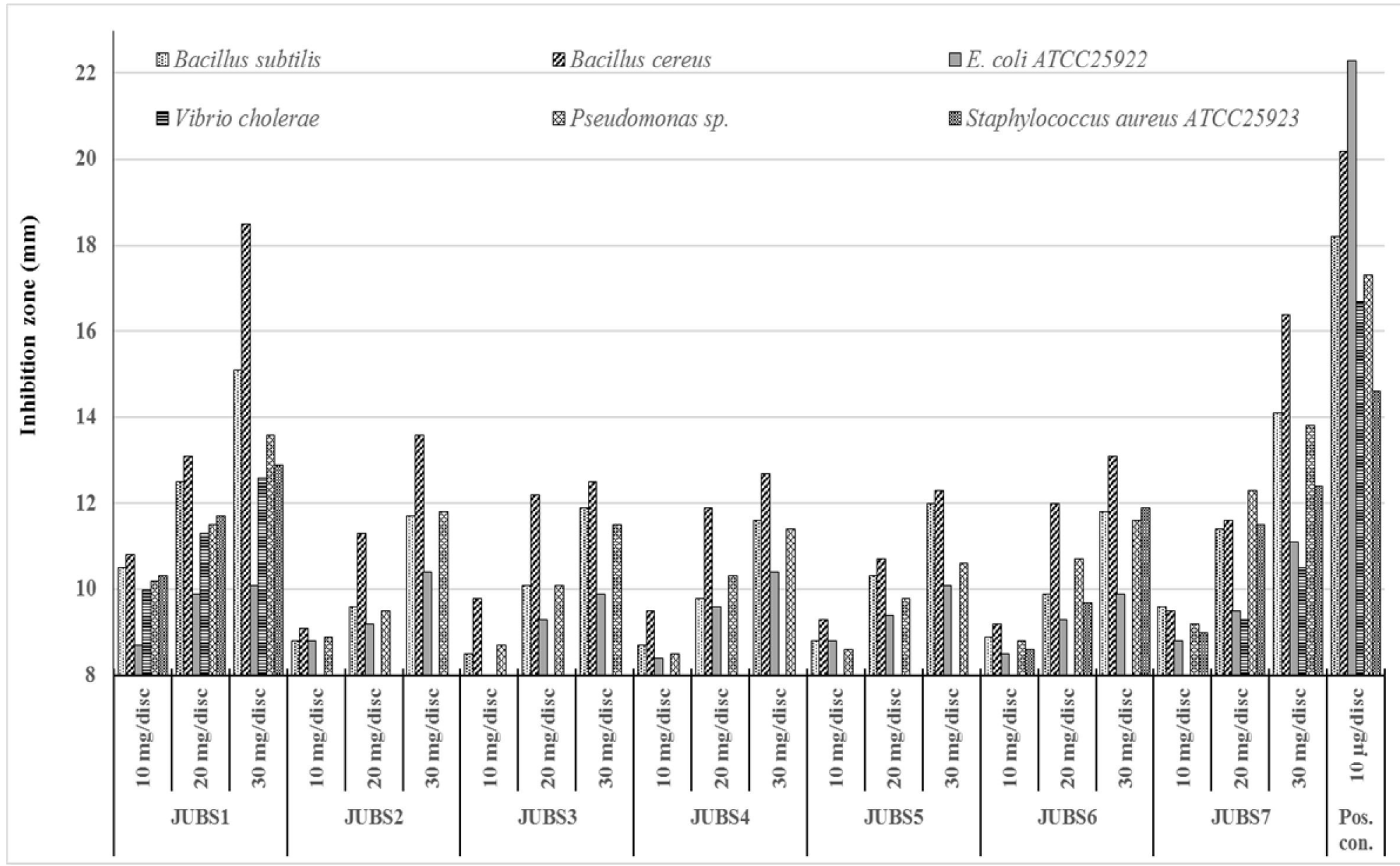

Fig. 1. Antibacterial activities of crude methanolic extracts of seven brinjal (S. melongena) samples using disc diffusion method. Positive control= Streptomycin $10 \mu \mathrm{g} / \mathrm{disc}$ 
of brinjal cultivars in comparison to Vincristine Sulphate $\left(\mathrm{LC}_{50}=0.069 \mathrm{mg} / \mathrm{ml}\right)$. Concentration dependent increment in percent mortality of Brine Shrimp nauplii produced by the methanolic extract of JUBS7 collected from Mymensingh with $\mathrm{LC}_{50}=$ $59.91 \mathrm{mg} / \mathrm{ml}$ after 6 hours indicates the presence of cytotoxic principles in the extract followed by JUBS5 with an $\mathrm{LC}_{50}=79.16 \mathrm{mg} / \mathrm{ml}$. However, after 6 hours the $\mathrm{LC}_{50}$ values of rest of the samples namely JUBS1, JUBS2, JUBS3, JUBS4 and JUBS6 ranged between $95 \mathrm{mg} / \mathrm{ml}$ to $216 \mathrm{mg} / \mathrm{ml}$.

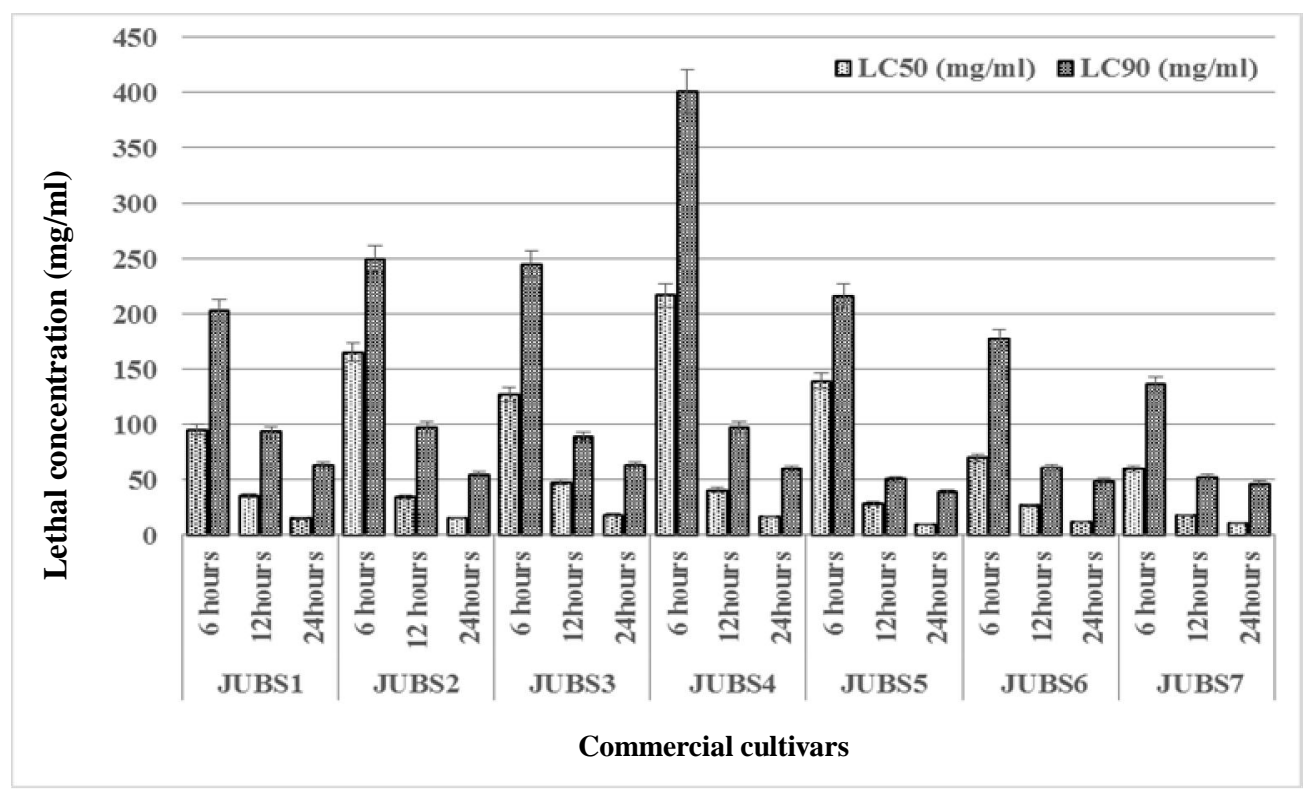

Fig. 2. $\mathrm{LC}_{50}$ and $\mathrm{LC}_{90}$ value of seven brinjal cultivars after 6,12 and 24 hours

After 12 hours the $\mathrm{LC}_{50}$ values of all the samples ranged between 17.88 to $47.38 \mathrm{mg} / \mathrm{ml}$ and 11.19 to $18.38 \mathrm{mg} / \mathrm{ml}$ after 24 hours respectively (Fig. 2). Dried fruit extract of Solanum nigrum have been reported to show cytotoxicity with $\mathrm{LC}_{50}$ value of $63.10 \mu \mathrm{g} / \mathrm{ml}$ following brine shrimp lethality test (Karmakar et al., 2010). According to Bello et al. (2005) saponins and tannins have been reported to exhibit cytotoxic effects and growth inhibition making them suitable as tumor inhibiting agents. However, Amash et al. (2007) showed that pipit brinjal had cytotoxic effects against MDA-MB-231, CaOV3 and HepG2 with IC50 value (concentration causing 50\% inhibition of the tumor cell line) of 93.5, 6.15 and $35.4 \mu \mathrm{g} / \mathrm{ml}$, respectively.

Antioxidant potential was evaluated using DPPH (1,1-diphenyl-2-picrylhydrazyl) free radical scavenging assay. In the present experiment, DPPH free radical scavenging activity was found maximum sample JUBS7 (87.64\%) and minimum in sample JUBS5 $(80.79 \%)$. Nonetheless, rest of the samples namely JUBS1, JUBS2, JUBS3, JUB4 and JUBS6 shown above $80 \%$ DPPH free radical scavenging activity that ranged between 81.80 to $87.07 \%$ (Fig. 3). 


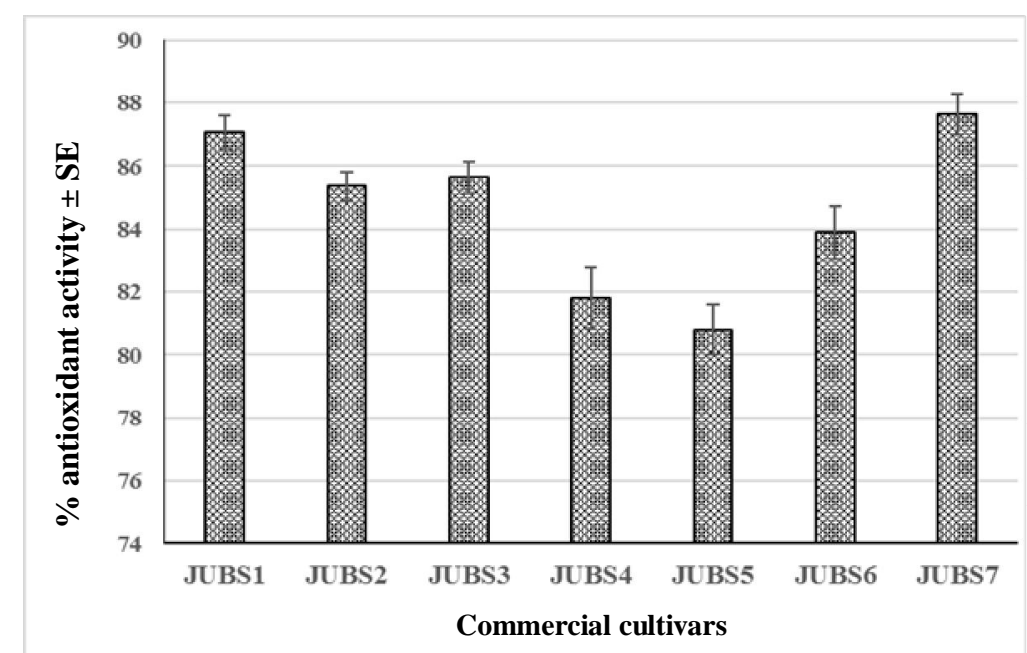

Fig. 3. DPPH free radical scavenging activity of crude extract of seven brinjal cultivars

The present results on DPPH free radical scavenging activity of different cultivars of brinjal corroborates with the findings of Nisha et al. (2009). Noda et al. (1998) found that extracts from brinjal fruit skin possess high capacity in scavenging of superoxide free radicals and inhibition of hydroxyl radical generation by chelating ferrous iron.

Polyphenols are the large group of phytochemicals that are gaining acceptance as being responsible for the health benefits associated with fruits and vegetables. Because of their chemical structure, plant polyphenols can scavenge free radicals and inactive other prooxidants, and also interact with a number of biological relevance. Total phenolic content of the crude extract of brinjal cultivars were determined by Folin-Ciocalteu reagent. Maximum phenolic content observed in this experiment was $9.292 \mathrm{mg} \mathrm{GAE} / \mathrm{g}$ in sample JUBS7 followed by JUBS1 expressed as $8.312 \mathrm{mg}$ GAE/g (Fig. 4). While minimum amount of phenolic content was recorded in sample JUBS2 $(6.821 \mathrm{mg} / \mathrm{GAE} / \mathrm{g})$. The phenolic content varied irrespective to the color and size of fruit. In contrats to the present findings, Nisha et al. (2009) reported that extracts from purple colour small size brinjal fruit demonstrated better antioxidant activities than the other samples which may be attributed to the higher phenolic and anthocyanin content. Shaheen et al. (2013) reported that total phenol content (TPC) in different varieties of Solanum melongena L. ranged between $3.16 \pm 0.04-7.86 \pm 0.33 \mathrm{mg} \mathrm{GAE} / \mathrm{g}$ of fresh weight.

The present study suggests that fruits extract of S. melongena could be potential source of antimicrobial agent and natural antioxidant. Thus further extensive work on isolation of novel phytchemicals from brinjal extract may lead to find interesting therapeutic compound and future work in this regard is needed. 


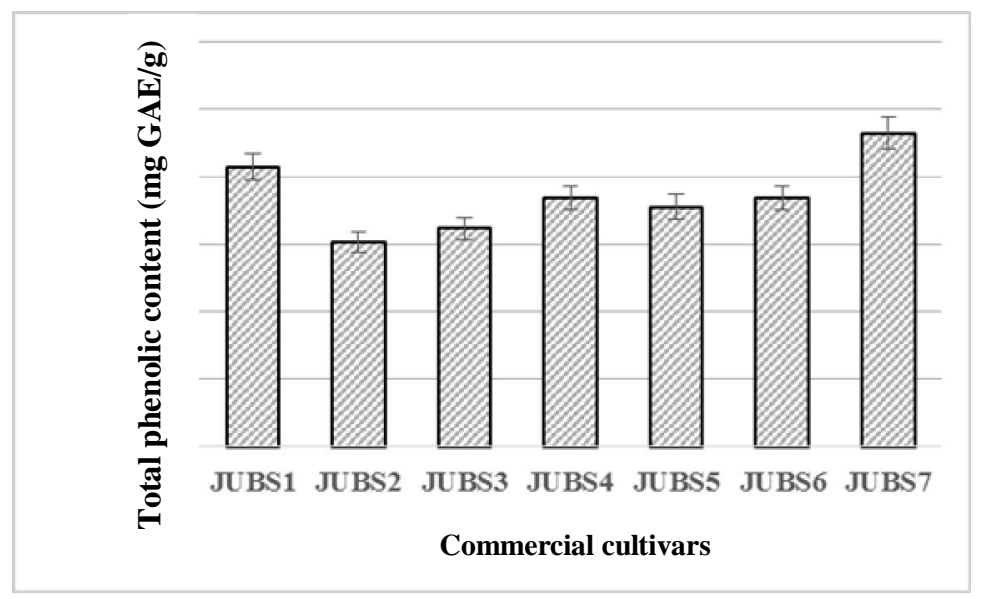

Fig. 4. Total phenolic content of methanolic crude extract of seven brinjal cultivars

Acknowledgment: This research work was supported by the special research grant of the Ministry of Science and Technology (MOST) in 2012-2013 fiscal years, which is gratefully acknowledged. Authors also wish to concede the laboratory support given by the Microbiology laboratory, department of Botany, JU in terms of research facilities.

\section{REFERENCES}

Agoreyo, W.E., Aliero, A.A. and Afolayan, A.J. 2012. Antimicrobial activity of Solanum tomentosum. African J. Biotechnol. 5(4): 369-372.

Al-Janabi, A. and Al-Rubeey, S.A. 2010. Detection of antimicrobial activity of Solanaum melogena L. (eggplant) against pathogenic microorganisms. J. Pharmacol. 2(15): 35-39.

Asmah, R., Fadzelly, A.B.M., Abdah, M.A., Eliana, A.N. and Hafzan, Y. 2007. Antioxidant activity, total phenolic content and cytotoxic activity of various types of eggplants. J. Trop. Agric. and Fd. Sci. 35(1): 91- 97.

Anushia, C., Sampathkumar, P. and Ramkumar, L. 2009. Antibacterial and antioxidant activities in Cassia auriculata. Global J. Pharmacol. 3(3): 127-130.

Aoshima, J., McDaugall, G.J. and Stewart, D. 2004. The inhibitory effect of berry polyphenols on digestive enzymes. Biofactors 23: 189-195.

Awe, I.S. and Sodipo, O.A. 2001. Purification of saponins of root of Blighia sapida Koenlg-Holl. Nigerian J. Biochem. Mol. Biol. 16 (37), 201-204.

Bauer, A.W., Kirby, W.M., Sherris, J.C. and Turck, M. 1966. Antibiotic susceptibility testing by a standardized single disk method. Am. J. Clin. Pathol. 45(4):493-496.

Bello, G., Ren-You Gan, F.R., Zhang, Y., Qin, X. and Kuang, L. 2005. Total phenolic contents and antioxidant capacities of selected Chinese medicinal plants. Intl. J. Mol. Sci. 11: 23622372.

Blois, M.S. 1958. Antioxidant determinations by the use of a stable free radical. Nature 181: 11991200.

Chinedu, S.N., Olasumbo, A.C., Eboji, O.K., Emiloju, O.C., Arinola, O.K. and Dania, D.I. 2011. Proximate and phytochemical analysis of Solanum aethiopicum L. and Solanum Macrocarpon L. fruits. Res. J. Chem. Sci. 1: 63-71.

Cowan, M.M. 1999. Plant products as antimicrobial agents. Clin. Microbiol. Rev. 12(4): 564-582. 
Friedman, M., Fitch, T.E., Levin, C.E. and Yokoyama, W.H. 2000. Feeding tomatoes to hamsters reduces their plasma low density lipoprotein cholesterol and triglycerides. J. Food Sci. 65: 897-900.

Ghani, A. 2003. Medicinal plants of Bangladesh with chemical constituents and uses, $2^{\text {nd }}$ edn. Asiatic Society of Bangladesh, Dhaka, Bangladesh. pp. 603.

Gubarev, M.I., Enioutina, E.Y., Taylor, J.L., Visic, D.M. and Daynes, R.A. 1998. Plant-derived glycoalkaloids protect mice against lethal infection with Salmonella tvphimurium. J. Phytochem. Herbal Med. 12: 79-88.

Harborne, J.B. 1973. Phytochemical Methods. Chapman and Hall Ltd, London. pp. 336-341.

Herrera, E., Jimenez, R.O., Aruoma, Hercberg, S., Sanchez-Garcia, I. and Fraga, C. 2009. Aspects of antioxidant foods and supplements in health and disease. Nutrition Rev. 67(1): 140-144.

Karmakar, U.K., Tarafder, U.K., Sadhu, S.K., Biswas, N.N. and Shill, M.C. 2010. Biological investigations of dried fruit of Solanum nigrum Linn. J. Pharmacol. Sci. 3 (1): 38 - 45.

Mahmood, A., Mahmood, A. and Mahmood, M. 2012. In vitro biological activities of most common medicinal plants of family Solanaceae. World Appl. Sci. J. 17(8): 1026 - 32.

Mazza, G., Cacace, J.E. and Kay, C.D. 2004. Methods of analysis for anthocyanins in plants and biological fluids. J. AOAC Int. 87: 129-145.

Meyer, B.N., Ferringni, N.R., Putnum, J.E., Jacobson, L.B., Nichollasand, D.E. and McLaughlin, J.L. 1982. Brine shrimp: a convenient general bioassay for active plant constituents. Planta Med. 45: 31-34.

Nicoletti, I., Bello, C., De Rossi, A. and Corradini, D. 2008. Identification and quantification of phenolic compounds in grapes by HPLC-PDA-ESI-MS on a semimicro separation scale. $J$. Agric. Food Chem. 56: 8801-8808.

Nisha, P., Nazar, P.A. and Jayamurthy, P. 2009. A comparative study on antioxidant activities of different varieties of Solanum melongena. Food Chem. Toxicol. 47(10): 2640-2644.

Noda, Y., Kaneyuki, T., Igarashi, K., Moriand, A. and Pacer, L. 1998. Antioxidant activity of nasunin, an anthocyanin in eggplant. Res Com. Molecular Path. Pharma. 102(2): 175-187.

Odebiyi, D. and Sofowora, A. 1978. Medicinal plants and traditional medicine in Africa, $1^{\text {st }}$ edn. John Wilay and sons Limited, New York. pp. 55-56.

Obadoni, B.O. and Ochuko, P.O. 2001. Phytochemical studies and comparative efficacy of the crude extracts of some Homostatic plants in Edo and Delta states of Nigeria. Global J. Pure Appl. Sci. 8: 203-208.

Shaheen, N., Kurshed, A.A.M., Karim, K.M.R., Mohiduzzaman, M., Banu, C.P., Begum, M. and Ishikawa, Y.T. 2013. Total phenol content of different varieties of brinjal (Solanum melongena L.) and potato (Solanum tuberosum L.) Growing in Bangladesh. Bangladesh J. Bot. 42(1): 175-177.

Sinden, S.L., Sanford, L.L., Cantelo, W.W. and Deahl, K.L. 1986. Leptine glycoalkaloids and resistance to the Colorado potato beetle (Coleoptera: Chrysomelidae) in Solanum chacoense. Environ. Entomol. 15(5): 1057-1062.

Sofowora, A. 1993. Medicinal Plants and Traditional Medicinal in Africa. 2nd Ed. In: Screening Plants for Bioactive Agents. Sunshine House, Ibadan, Nigeria: Spectrum Books Ltd; pp. 134-156.

Sudheesh, S., Sandhya, C., Koshy, S.A. and Vijayalakshmi, N.R. 1999. Antioxidant activity of flavonoids from Solanum melongena. Phytotherapy 13: 393-396.

Trease, G.E. and Evans, W.C. 1989. Trease and Evan's Textbook of Pharmacognosy, $13^{\text {th }}$ edn. Cambridge University Press, London. pp. 546.

Vinson, J.A., Dabbagh, Y.A., Serry, M.M. and Jang, J. 1995. Plant flavonoids, especially tea flavonols, are powerful antioxidants using an in vitro oxidation model for heart disease. $J$. Agric. Food Chem. 43(11): 2800-2802. 